TABLE Summary of clinical findings in three cases of trisomy $9 q$.

\begin{tabular}{|c|c|c|c|}
\hline & Turleau et al 1 & Faed et al 2 & Present case \\
\hline Trisomic segment & $\mathrm{q} 11 \rightarrow \mathrm{q} 33$ & $\mathrm{q} 12 \rightarrow \mathrm{q} 32$ & $\mathrm{q} 12 \rightarrow \mathrm{q} 32$ \\
\hline Pregnancy (wk) & 40 & 36 & 37 \\
\hline Birth weight (g) & 2300 & 1730 & 2300 \\
\hline Length $(\mathrm{cm})$ & 50 & & 44 \\
\hline Head circumference $(\mathrm{cm})$ & $32 \cdot 5$ & & 29 \\
\hline Sex & $\mathbf{M}$ & $\mathbf{M}$ & $\mathbf{F}$ \\
\hline Asphyxia or neonatal problems & + & + & - \\
\hline Microdolichocephaly & + & + & + \\
\hline Slender face & + & $(+)$ & + \\
\hline Hypotelorism & + & - (Wide set) & + (Borderline) \\
\hline Horizontal palpebral fissures & + & + & + \\
\hline Epicanthic folds & + & + & + \\
\hline Strabismus & + & + & - \\
\hline Nose & Beaked & Beaked & Beaked \\
\hline Mouth & Small & Small & Small \\
\hline Lips & & & Thin upper lip overlaps lower lip \\
\hline Micrognathia & + & + & + \\
\hline Abnormality of the thumbs & + & & + \\
\hline Hip joint & & Flexion contracture & Unilateral dislocation \\
\hline Feet & Long toes with abnormal implantation & & Normal \\
\hline Internal malformation & Ventricular septal defect & & \\
\hline Thriving & Poor & Poor & Poor \\
\hline Mental retardation & + & + & + \\
\hline Natural history & Alive at 5 years & Alive at 4 years & Alive at 2 years \\
\hline
\end{tabular}

\section{Discussion}

As far as we are aware, there have been only two reported cases of trisomy $9 q$ in which most of the long arm is involved (table). The clinical features common to all three cases are: low birth weight, failure to thrive, mental retardation, narrow face, epicanthic folds, beaked nose, small mouth, micrognathia, and good life expectancy during infancy. These similarities should make it possible to recognise this abnormality on the basis of clinical findings. It is remarkable that the presence of such a large extra segment has a relatively mild effect on the patient.

The authors are grateful for technical assistance to Mr T Yokochi, Shizuoka Children's Hospital.

\section{References}

1 Turleau C, de Grouchy J, Chavin-Colin F, et al. Partial trisomy 9q: a new syndrome. Humangenetik 1975;29: 233-41.

2 Faed M, Robertson J, Brown S, Smail PJ, Muckhart R日. Pure partial trisomy for long arm of chromosome 8 . $J$ Med Genet 1976;13:239-42.

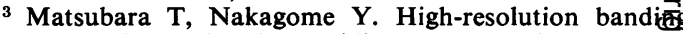
by treating cells with acridine orange before fixation Cytogenet Cell Genet 1983;35:148-51.

4 Schweizer D, Ambros P, Andrle M. Modification of DAPI banding on human chromosomes by prestaining $\mathbb{D}$ with a DBA-binding oligopeptide antibiotic, distamycin A. Exp Cell Res 1978;111:327-32.

Correspondence and requests for reprints to Dr Y Nakahori, Department of Human Genetics, National Institute of Genetics, Yata 1, 111 Misima, Sizuoka-ken, 411 Japan.

\title{
Familial centric fission of chromosome 4
}

\section{G DEL PORTO*, C DI FUSCO*, M BALDI*, P GRAMMATICO*, AND E D'ALESSANDRO $\dagger$}

*II Cattedra di Genetica Medica, Università La Sapienza, Roma; and †Cattedra di Genetica Medica, Università degli Studi, L'Aquila, Italy.

SUMMARY A centric fission of chromosome 4 is described in the proband and his mother, both phenotypically normal. In addition, partial monosomy for the long arm or the short arm or

Received for publication 31 December 1983 Accepted for publication 2 February 1984. both of chromosome 4 may have been present in? two of the proband's sibs who died in infancy and $\stackrel{\circ}{\circ}$ childhood, respectively.

Centric fission of a chromosome consists of a break $\frac{0}{0}$ in the centromeric region, which results in the 
separation of the centromere into two portions, and consequent formation of two stable telocentric chromosomes. Such an event, well known in animals, was first described in humans by Sinha et $a .^{1}{ }^{1}$ Other cases of centric fission in man have been reported by Hansen, ${ }^{2}$ Fryns et al, ${ }^{3}$ and more recently by Janke. ${ }^{4}$

The only case of centric fission of chromosome 4 reported so far was described by Dallapiccola et $a l^{5}$ in the mother of two patients with trisomy $4 \mathrm{p}$.

\section{Case report}

A couple requested genetic counselling because of familial infertility. A pedigree analysis, which was uninformative for the wife, indicated, however, con- sanguinity in the husband's family, his parents being first cousins (fig 1). In addition, the sibship of the husband's mother (IILA) included three spontaneous abortions and two deaths in early childhood, and the husband's sibship (IVB) also included two spontaneous abortions and two deaths (IV.11 and IV.15).

Chromosome analysis showed a normal karyotype for the wife and a $47, \mathrm{XY}$,cen fiss 4 complement for the husband. As a result, the proband's parents were also examined. The father (III.7) had a normal karyotype, while the mother (III.8) was found to have a centric fission of chromosome 4.

The clinical data regarding the dead children, IV.11 and IV.15, were based on the mother's report and on examination of photographs (table 1).

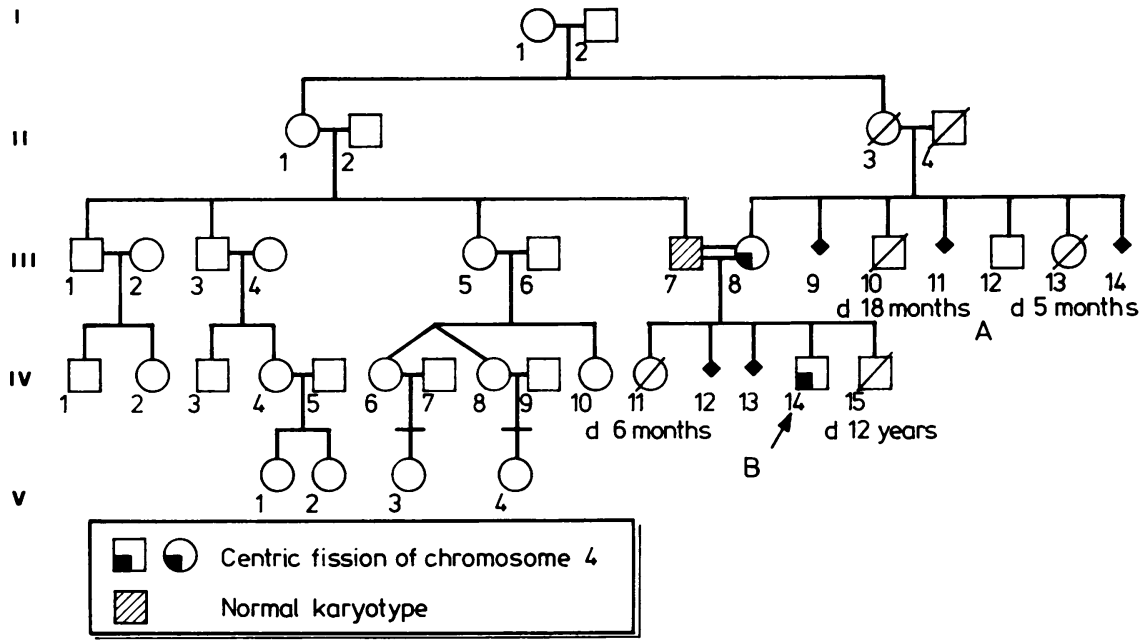

FIG 1 Family pedigree.

TABLE 1 Clinical data of patients IV.II and IV.15.

\begin{tabular}{lll}
\hline Clinical data & $I V .11$ & $I V .15$ \\
\hline Birth weight & Normal & Normal \\
Growth & Normal & Normal \\
Psychomotor retardation & Severe & Severe \\
Delay in walking & - & Later than 2 years \\
Delay in language development & - & Later than 2 years \\
Convulsions & Frequent & Frequent \\
Microcephaly & Not identified & Present \\
Glabella & Normal & Prominent \\
Palpebral fissures & Mongoloid slant & Not identified \\
Strabismus & Absent & Present \\
Nose & Wide and flat bridge & Beaked \\
Ear abnormality & Pointed & Large, low set \\
Micrognathia & Doubtful & Present \\
Hypoplasia of mandible & Moderate & Present \\
Cardiac defects & Not identified & Present \\
Age at death & 6 months & 12 years \\
\hline
\end{tabular}




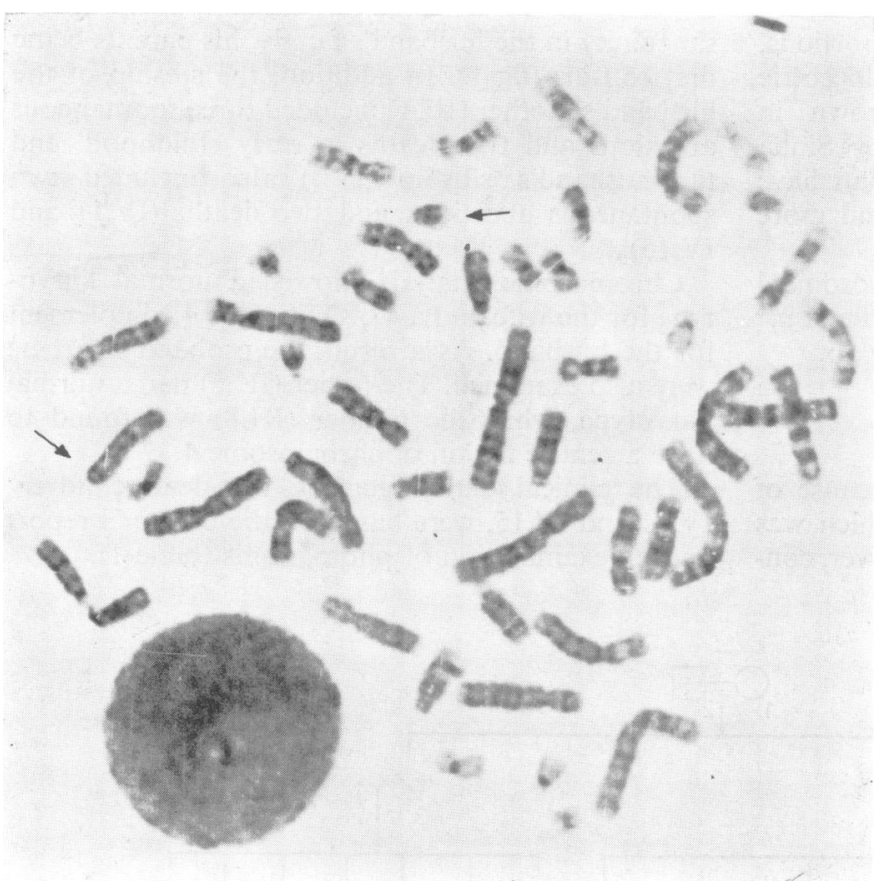

FIG 2 Chromosomal pattern of the proband $\vec{\omega}$ (GTG banding).

TABLE 2 Clinical data identified in partial aberrations of chromosome 4.

\begin{tabular}{|c|c|c|c|c|}
\hline Clinical data & $4 p-$ & $4 q-$ & $4 p+$ & $4 q+$ \\
\hline Birth weight & Low +++ & Normal & Low + & Low $t+t$ \\
\hline Growth delay & +++ & +++ & +++ & +++ \\
\hline Psychomotor retardation & +++ & +++ & +++ & +++ \\
\hline Delay in language development & ++ & ++ & $+t+$ & ++ \\
\hline Hypotonia & +++ & ++ & +++ & $+t+$ \\
\hline Convulsions & $++t$ & ++ & $++t$ & + \\
\hline Age of survival & 17 years & 4 years & Youth & - \\
\hline CNS malformations & Frequent & Rare & Rare & Rare \\
\hline Brachycephaly or oxycephaly & ++ & - & - & - \\
\hline Microcephaly & $++t$ & $+t+$ & ++ & $+t+$ \\
\hline Haemangiomas & ++ & - & - & -- \\
\hline Absence of scalp & ++ & Normal & Low hairline & Normal \\
\hline Hypertelorism & $+t+$ & +++ & +++ & ++ \\
\hline Coloboma & ++ & $++t$ & ++ & - \\
\hline Strabismus & ++ & - & $+t+$ & + \\
\hline Palpebral fissures & Antimongoloid & $\begin{array}{l}\text { Horizontal } \\
\text { mongoloid }\end{array}$ & Horizontal & $\begin{array}{l}\text { Horizontal or } \\
\text { slightly slanted }\end{array}$ \\
\hline Glabella & Prominent & Prominent & Prominent & Prominent \\
\hline Nose & Beaked & Wide and flat bridge & Low set, dysmorphic & Low set, dysmorphic \\
\hline Micrognathia & +++ & ++ & - & ++ \\
\hline Cleft lip and/or palate & +++ & - & + & - \\
\hline Hypoplasia of mandible & + & - & - & - \\
\hline Cardiac defects & ++ & ++ & + & + \\
\hline Accessory ribs & + & ++ & - & - \\
\hline Vertebral malformations & + & - & $++t$ & - \\
\hline Hypoplasia of pelvis & + & - & ++ & - \\
\hline Renal anomalies & + & ++ & + & $+t+$ \\
\hline Abdominal anomalies & + & + & + & + \\
\hline Hip dislocation & + & ++ & - & - \\
\hline Flexion creases of 4 th finger & +++ & - & + & ++ \\
\hline Dermatoglyphs & Reduced & Normal & Increased & Normal \\
\hline Camptodactyly & + & - & +++ & - \\
\hline Flat or displaced feet & ++ & ++ & ++ & + \\
\hline Clinodactyly & ++ & ++ & ++ & + \\
\hline Hypoplasia of external genitalia & $++t$ & - & $+t+$ & - \\
\hline Cryptorchidism & $+t+$ & - & $++t$ & $+t+$ \\
\hline
\end{tabular}

+++ severe, ++ moderate, + mild, - absent. 


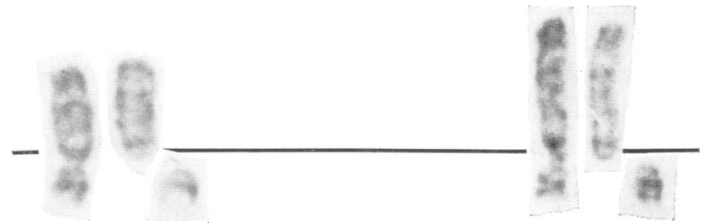

FIG 3 Partial karyotypes of the proband showing centric fission of chromosome 4 (GTG banding).

\section{Discussion}

This appears to be the first published case report of transmitted centric fission of chromosome 4 so far. It is interesting to observe the particular stability of human telocentric chromosomes, which involve a high risk of transmission of non-balanced gametes.

In sibships A and B there are early spontaneous abortions which could be attributed to the unbalanced form of the aberration. Another point worthy of attention is the possible clinical interpretation of the two children of sibship B, who died at 6 months and 12 years, respectively. Their phenotype was deduced from the clinical history and the photographs.

Table 2 lists the symptoms described in cases of partial aberrations of chromosome 4 and allows a comparison with those present in the two dead children as a possible aid to a specific diagnosis.

Of the various clinical manifestations described in table 1 , subject IV.11 presented with a normal birth weight, flat and wide nasal bridge, mongoloid slant, absence of strabismus, and died at 6 months. These symptoms are also found in cases of partial $4 q-$ suggesting that partial monosomy of the long arm of chromosome 4 was present in this child.

Subject IV.15 presented with a beaked nose, pronounced micrognathia, strabismus, and marked hypoplasia of the mandible. Death occurred at 12 years. This appears to be consistent with malformations found in partial monosomy of the short arm of chromosome 4 . In particular, the age of death is similar to the only case reported ${ }^{6}$ of survival through the first year of life in a subject with partial $4 p$ monosomy.

We would like to thank Mr Mario Sanchioni for his help with the photographs.

\section{References}

1 Sinha AK, Pathak S, Nora JJ. A human family suggesting evidence for centric fission and stability of a telocentric chromosome. Hum Hered 1972;22:423-9.

2 Hansen S. A case of centric fission in man. Hum Genet 1975;26:257-9.

3 Fryns JP, Bulcke I, Hens L, Van den Berghe H. Balanced transmission of centromeric fission product in man. Hum Genet 1980;54:127-8.

4 Janke D. Centric fission of chromosome 7 in three generations. Hum Genet 1982;60:200-1.

5 Dallapiccola B, Mastroiacovo P, Gandini E. Centric fission of chromosome 4 in the mother of two patients with trisomy 4p. Hum Genet 1976;31:121-5.

6 Miller OJ, Breg WR, Warburton D, et al. Partial deletion of the short arm of chromosome $4(4 \mathrm{p}-)$ : clinical studies in five unrelated patients. J Pediatr 1970;77:792-9.

Correspondence and requests for reprints to Professor Giuseppe Del Porto, Via San Calepodio 7, 00152 Rome, Italy.

Mosaic Down's syndrome with de novo 45,XX, $-21,-22,+\mathrm{t}(21 \mathrm{q} ; 22 \mathrm{q}) / 46$, $\mathrm{XX},-21,+\mathrm{t}(21 \mathrm{q} ; 21 \mathrm{q})$ rearrangement

\author{
A T THARAPEL*, R REDHEENDRAN†, C B MANKINEN + , AND \\ M K KUKOLICH $\dagger$ \\ * Department of Pediatrics, University of Tennessee Center for the Health Sciences, Memphis, \\ Tennessee; and $\dagger$ the Genetics Screening and Counselling Service, Denton, Texas, USA.
}

SUMMARY The occurrence of mosaic Down's syndrome with two independent Robertsonian translocation cell lines is very rare. Such a patient is reported here, in whom an unbalanced Robertsonian translocation between two chromoReceived for publication 28 November 1983. Accepted for publication 20 December 1983. somes 21 was detected in the majority of cells. The patient also revealed a minor cell line with a second Robertsonian translocation involving a chromosome 21 and a 22 . The chromosome translocations detected in this patient were de novo in origin. 